\title{
REVIEW
}

\section{SYSTEMIC HORMONAL AND PHYSIOLOGICAL ABNORMALITIES IN ANXIETY DISORDERS}

\author{
OLIVER G. CAMERON and RANDOLPH M. NESSE \\ Department of Psychiatry, University of Michigan Medical Center, Ann Arbor, Michigan, U.S.A.
}

(Received 15 September 1986; in final form 9 October 1987)

\begin{abstract}
SUMMARY
Among the studies of systemic hormonal and physiological abnormalities associated with anxiety disorders, the most consistent and extensive findings suggest (a) peripheral adrenergic hyperactivity (including increases in norepinephrine but not epinephrine) and functional dysregulation, (b) increased incidence of mitral valve prolapse in panic patients, and (c) normal suppressibility of the hypothalamic-pituitary-adrenal cortical endocrine system with dexamethasone in panic patients. Other less-certain findings include (a) increased circulating concentrations of plasma ACTH and/or cortisol, and prolactin, in panic patients, (b) increased platelet monoamine oxidase activity in generalized anxiety and/or panic patients, (c) decreased gonadal axis activity in some anxious individuals, (d) decreased nighttime melatonin plasma concentrations in panic patients, and (e) peripheral $\alpha_{2}$ and $B$-adrenoreceptor down-regulation, with normal serotonin binding parameters. These findings, taken together, provide tentative support for dysfunction in adrenergic and GABAergic central nervous system mechanisms in people with anxiety disorders. Abnormal anxiety and normal stress both show evidence of adrenergic hyperactivity; however, there appear to be differences in hormonal profiles, especially the apparent lack of increase of epinephrine during panic attacks, as well as differences in the reactivity of the system, and in the "trigger" mechanisms which determine when the response occurs.
\end{abstract}

\section{INTRODUCTION}

RECENT ADVANCES in diagnosis and treatment have led to a renewal of interest in the pathophysiology of anxiety symptoms and anxiety disorders. Because the central nervous system is relatively inaccessible to study in humans, most research has been either with animal models of anxiety or with presumptive peripheral psychobiological markers; it is usually assumed that peripheral changes provide "downstream" or "final common path" indicators of central nervous system activity. Human studies have typically involved one of two paradigms: study of peripheral changes occurring in normal individuals under stressful "anxiety"-provoking circumstances (natural or experimentally induced), or study of differences between normals and individuals with anxiety disorders. Although it is often assumed, at least implicitly, that by studying one paradigm, knowledge is also gained about the other, there is little empirical support

Correspondence to be addressed to: Oliver G. Cameron, M.D., Ph.D., Department of Psychiatry, University of Michigan Medical Center, 900 Wall Street, Ann Arbor MI 48109, USA. 
TABLE I. ENDOCRINE FUNCTIONING IN ANXIETY DISORDERS

\begin{tabular}{|c|c|c|c|c|c|}
\hline Hormone & $\begin{array}{l}\text { Stress in } \\
\text { Normals }\end{array}$ & \begin{tabular}{|l|} 
Panic/Agoraphobia \\
\end{tabular} & \begin{tabular}{|c|} 
Generalized \\
Anxiety Disorder \\
\end{tabular} & Phobias & $\begin{array}{l}\text { Other } \\
\text { Groups }\end{array}$ \\
\hline Catecholamines & Elevated & $\begin{array}{l}\text {-Usually elevated levels } \\
\text { (may reflect reactivity } \\
\text { abnormality) } \\
\text {-Attack levels often normal } \\
\text {-Variable response to lactate }\end{array}$ & Elevated & Elevated & $\begin{array}{l}\text { Elevated in } \\
\text { mixed anxiety } \\
\text { and depression }\end{array}$ \\
\hline MHPG & $\begin{array}{l}\text { Correlated } \\
\text { with } \\
\text { anxiety } \\
\text { level }\end{array}$ & $\begin{array}{l}\text {-Sometimes elevated } \\
\text {-Yohimbine stimulates }\end{array}$ & & & $\begin{array}{l}\text { Positively } \\
\text { correlated with } \\
\text { anxiety in } \\
\text { depressed and } \\
\text { "trait-anxious" } \\
\text { patients }\end{array}$ \\
\hline Corticosteroids & Elevated & $\begin{array}{l}\text {-Either normal or elevated } \\
\text {-DST normal } \\
\text {-Variable response to lactate }\end{array}$ & $\begin{array}{l}\text { Either normal or } \\
\text { elevated }\end{array}$ & $\begin{array}{l}\text { Elevated - } \\
\text { may be a } \\
\text { "novelty" } \\
\text { effect }\end{array}$ & $\begin{array}{l}\text { Elevated by } \\
\text { caffeine in } \\
\text { normals }\end{array}$ \\
\hline $\begin{array}{l}\text { Growth } \\
\text { Hormone }\end{array}$ & $\begin{array}{l}\text { Some } \\
\text { elevation }\end{array}$ & $\begin{array}{l}\text { - Normal, elevated or } \\
\text { decreased } \\
\text { - Response to clonidine } \\
\text { stimulation may be blunted } \\
\text { - Normal response to lactate }\end{array}$ & & $\begin{array}{l}\text { Often } \\
\text { elevated }\end{array}$ & \\
\hline Prolactin & $\begin{array}{l}\text { Some } \\
\text { elevation }\end{array}$ & \begin{tabular}{|l|}
-Elevated basal levels \\
-Cold pressor normal \\
-Elevated or normal response \\
to lactate \\
"SSpontaneous" panic \\
elevation probable, but \\
decreased in situational \\
attacks
\end{tabular} & $\begin{array}{l}\text { Seems to be } \\
\text { normal }\end{array}$ & Normal & \\
\hline Thyroid Axis & $\begin{array}{l}\text { Some } \\
\text { elevation }\end{array}$ & $\begin{array}{l}\text {-Hyperthyroidism may } \\
\text { mimic panic } \\
\text {-Blunted TSH response to } \\
\text { TRH } \\
\text {-Some abnormalities in } \\
\text { women }\end{array}$ & & $\begin{array}{l}\cdot \mathrm{TSH}_{\text {normal }} \\
\cdot \mathrm{T}_{3} / \mathrm{T}_{4} \text { some- } \\
\text { times } \\
\text { elevated }\end{array}$ & \\
\hline Gonadal Axis & \begin{tabular}{|l} 
May be \\
decreased \\
-LH \& FSH \\
usually \\
normal
\end{tabular} & $\begin{array}{l}\text {-Lactate decreases } \\
\text {-Pregnancy may improve } \\
\text { symptoms }\end{array}$ & & & $\begin{array}{l}\text { Fluctuations in } \\
\text { menstrual cycle } \\
\text { may affect re- } \\
\text { ports of anxiety } \\
\text { in normals and } \\
\text { panic patients }\end{array}$ \\
\hline $\begin{array}{l}\text { Glucose } \\
\text { Regulation }\end{array}$ & $\begin{array}{l}\text { Glucose, } \\
\text { insulin, } \\
\text { glucagon } \\
\text { may change }\end{array}$ & $\begin{array}{l}\text {-Insulin not affected by } \\
\text { lactate } \\
\text { - Not related to hypoglycemia }\end{array}$ & & $\begin{array}{l}\text { Insulin } \\
\text { increased, } \\
\text { glucagon } \\
\text { normal } \\
\end{array}$ & \\
\hline Melatonin & & May be decreased & & & \\
\hline
\end{tabular}


for this point of view. Thus, the large body of research on the psychobiology of stress (e.g., Van Toller, 1979; Rose, 1980) might be about mechanisms totally different from those which are associated with anxiety disorders. In order to understand the pathophysiology of abnormal anxiety, individuals with these disorders must be studied specifically.

The purpose of this article is to review studies of the psychobiological characteristics of individuals with anxiety disorders. Most of the studies have focused on endocrine and/or autonomic nervous system changes; these will be reviewed separately, including studies of peripheral receptor status. Following the review, the results will be integrated in an attempt to indicate what these studies tell about the pathophysiology of abnormal anxiety. Finally, strategies and new directions will be suggested, to further understand the pathophysiology, and ultimately the etiology, of pathological anxiety states.

Many of the studies described below did not use formalized diagnostic criteria to define the patient population under study. Studies in which diagnostic criteria are not explicitly specified typically appear to involve patients with panic attacks (with or without agoraphobia) and/or generalized anxiety disorder, as defined by DSM-III (American Psychiatric Association, 1980) or DSM-III-R (American Psychiatric Association, 1987). Patients designated as "neurocirculatory asthenia" or related terms may or may not represent the same patients; the pathophysiology of these patients have also been studied (e.g., Mantysaari, 1984).

\section{Psychoendocrine Findings}

Patients with anxiety disorders show differences in the circulating concentrations of several hormones in comparison to normal subjects. These include catecholamines and MHPG, cortisol and ACTH, growth hormone, prolactin, thyroid axis hormones, gonadal axis hormones, glucose regulatory hormones, melatonin, and $\beta$-endorphin. The endocrine abnormalities are summarized in Table I.

Catecholamine concentrations studied in anxious people include epinephrine, norepinephrine, dopamine, and catecholamine metabolites, especially 3-methoxy-4-hydroxyphenethyleneglycol (MHPG). Norepinephrine is of interest as a marker of systemic adrenergic activity, while epinephrine is usually considered to be released as part of a "stress" reaction. Catecholamine metabolites are indicators of both peripheral and central (especially MHPG) nervous system adrenergic activity.

Stress or anxiety in normal subjects usually produces elevations of circulating catecholamines (Frankenhaeuser, 1971; Ursin et al., 1978; Van Toller, 1979; Rose, 1980; Lader, 1982; Axelrod \& Reisine, 1984). Catecholamine elevations have also been observed in patients with mixed anxiety and depression (Wyatt et al., 1971), specific phobias (Chosy et al., 1970; Nesse et al., 1985a), and generalized anxiety (Mathew et al., 1980a; 1980c; 1981a). MHPG appears to be positively correlated with anxiety levels in normal subjects and psychiatric patients, including high trait-anxious individuals, although the actual levels may not be significantly elevated (Uhde et al., 1982; Potter et al., 1983; Davis et al., 1985). People with high ratings of trait anxiety have a higher plasma MHPG response to pain and a greater heart rate response to intramuscular epinephrine than low trait-anxiety individuals (Mathew et al., 1980c; Uhde et al., 1982). In another study, high trait anxious people did not have an elevation of resting plasma epinephrine or norepinephrine; however, moderate exercise did lead to an exaggerated norepinephrine rise (Peronnet et al., 1986).

Basal plasma epinephrine, norepinephrine, MHPG and possibly dopamine may be elevated in panic disorder patients compared to normal subjects (Ballenger et al., 1984; Cameron et al., 1984; Nesse et al., 1984; Villacres et al., 1987), although we found normal basal supine and posturally stimulated concentrations (unpublished data), another study reported pre-lactate MHPG concentration to be normal (Pohl et al., 1987), and a third study reported norepinephrine levels and kinetics to be normal (Villacres et al., 1987). In ambulatory patients, 
urinary norepinephrine, but not epinephrine, is also significantly elevated (Nesse et al., 1985b), but urinary MHPG may be decreased, normal, or increased (Hamlin et al., 1983; Sheehan et al., 1983a; Roy-Byrne et al., 1986a). Challenge testing has yielded conflicting results concerning epinephrine and norepinephrine changes associated with lactate infusions (Appleby et al., 1981; Liebowitz et al., 1985; Carr et al., 1986); increases ranged from moderate to nonexistent. MHPG was minimally responsive to lactate infusions (Carr et al., 1986; Pohl et al., 1987), and isoproterenol infusion (Pohl et al., 1987). Challenge testing with yohimbine, an $\alpha_{2}-$ adrenergic receptor antagonist, demonstrated increases in MHPG in both patients and normals, with more severe panic patients showing the largest increases (Charney et al., 1983; 1984; Charney \& Heninger, 1985a; 1985b); clonidine, an $\alpha_{2}$ agonist, produced greater MHPG decreases in patients than normals (Charney \& Heninger, 1986a). Caffeine-induced increases in anxiety did not raise MHPG (Uhde et al., 1984a; Chamey et al., 1985), while situationally produced anxiety in panic patients did produce increases in MHPG in one study (Ko et al., 1983), but not in another (Woods et al., 1987). Norepinephrine and MHPG were minimally changed during "spontaneous" (unexpected) panic attacks, and epinephrine showed no change at all (Cameron et al., 1987); it was suggested that posture and activity levels might play a role in hormonal (and physiological) reactivity in these patients. In summary, catecholamines and catecholamine metabolites are frequently elevated in patients with anxiety disorders; however, elevations have not always been observed and are clearly not a sine qua non for anxiety symptoms.

Cortisol in humans is released from the adrenal cortex in response to ACTH. Corticosteroids are elevated under stressful conditions in normal subjects (Mason et al., 1965; Ursin et al., 1978; Van Toller, 1979; Rose, 1980; Axelrod \& Reisine, 1984). In patients with simple phobias, plasma cortisol elevations are associated with acute phobic anxiety in some circumstances but not in others (Curtis et al., 1976; 1978; Fredrikson et al., 1985; Nesse et al., 1985a). In patients with generalized anxiety urinary corticosteroid excretion has been reported as both normal and elevated (Persky et al., 1956; Rosenbaum et al., 1983); also, there is one report of an increased incidence of abnormal dexamethasone suppression tests (DST) (Schweizer et al., 1986a). Patients with obsessive-compulsive disorders are also reported to have an increased incidence of positive DST's (Cameron et al., 1986a; Zohar \& Insel, 1987). In patients with panic disorder, resting plasma cortisol concentrations are normal or mildly elevated (Nesse et al., 1984; Villacres et al., 1987; Holsboer et al., in press), and the incidence of abnormal dexamethasone suppression tests is normal or only slightly increased (Curtis et al., 1982; Lieberman et al., 1983; Sheehan et al., 1983b; Avery et al., 1985; Peterson et al., 1985; Roy-Byme \& Uhde, 1985; Bridges et al., 1986). Studies of panic patients have reported both normal and elevated basal cortisol and ACTH concentrations as well as reduced cortisol and ACTH responses to CRH (corticotropin releasing hormone) (Roy-Byrne \& Uhde, 1985; RoyByme et al., 1985; 1986b; Holsboer et al., in press). Cortisol changes were inconsistent during "spontaneous" panic attacks, although cortisol elevations appeared to be correlated with attack severity (Cameron et al., 1987): Similar to the reports on catecholamines, there are conflicting data on whether lactate-induced panic is associated with cortisol elevations (Appleby et al., 1981; Liebowitz et al., 1985, Carr et al., 1986). Cortisol was elevated in caffeine-induced anxiety in normal subjects (Uhde et al., 1984a; Charney et al., 1985) and panic patients (Charney et al., 1985), but cortisol during situational panic attacks was normal (Woods et al., 1987). Cortisol was also increased more in yohimbine-induced panic than in normals (Charney et al., 1987). Finally, the cortisol response to the mirror-drawing test was reported to be greater in "neurotic" (anxious?) subjects than in normals (Miyabo et al., 1976). Thus, there is some evidence of increased hypothalamic pituitary-adrenal cortical (HPA) activity under some circumstances in anxiety disorders; nevertheless, in panic patients, the axis appears to be normally suppressible, as indicated by the DST results. 
Other hormones, including growth hormone, prolactin, thyroid, and gonadal hormones are also systemic indicators of hypothalamic-pituitary function. The various hormones are regulated by different releasing factors and different combinations of neurotransmitter inputs at the hypothalamic level. Growth hormone is responsive to stress, although not as strongly or reliably as catecholamines or cortisol (Ursin et al., 1978; Van Toller, 1979; Rose, 1980). Plasma growth hormone increases also occur in some phobics during in vivo exposure (Curtis et al., 1979; Nesse et al., 1985a). Resting growth hormone may be elevated in panic patients (Nesse et al., 1984; Uhde et al., 1985), and the growth hormone response to clonidine challenge appears to be blunted (Uhde et al., 1985; 1986; Charney \& Heninger, 1986a). Growth hormone response to lactate was reported to be similar in panic patients and normals (Carr et al., 1986). Growth hormone may be decreased during situational panic attacks (Woods et al., 1987). And, like cortisol, growth hormone was reported to be more responsive to the mirror-drawing test in "neurotic" patients (Miyabo et al., 1976). Growth hormone responses to "spontaneous" panic attacks showed substantial inter-subject differences (Cameron et al., 1987).

Circulating prolactin concentrations are sometimes elevated in association with stress (Rose, 1980), but do not change in association with phobic anxiety (Nesse et al., 1980), relaxation treatment of generalized anxiety (Mathew et al., 1979), or the cold pressor test in panic patients (Grunhaus et al., 1983). Prolactin increases have been observed at rest in panic patients and in response to lactate-induced panic in two studies (Appleby et al., 1981; Liebowitz et al., 1985), but not in a third (Carr et al., 1986). Prolactin responses to the serotonin precursor tryptophan were normal in panic patients (Charney \& Heninger, 1986b); hormonal responses (cortisol, growth hormone, prolactin) to MCPP, a serotonin agonist, also indicated normal serotonin activity in panic patients (Charney et al., 1987b). A prolactin increase occurred during "spontaneous" panic attacks (Cameron et al., 1987), but prolactin may be decreased during situational attacks (Woods et al., 1987).

Thyroid function changes are implicated in stress (McKenzie, 1974), including the similarity between thyrotoxic and somatic anxiety symptoms (Lader, 1981), the increased incidence of thyroid dysfunction in phobias of various kinds (Lindemann et al., 1984), the possible association between hyperthyroidism and panic attacks (Katerndahl \& Vande Creek, 1983) and generalized anxiety (Kathol et al., 1986), and blunted TSH (and prolactin) responses to TRH (thyrotropin releasing hormone) in panic patients (Roy-Byrne \& Uhde, 1985; RoyByme et al., 1985). Plasma TSH levels did not change during phobic anxiety (Nesse et al., 1982). An increased frequency of thyroid hormone abnormalities was reported in women with panic attacks (Matuzas et al., 1987).

Unlike the increases seen in several other hormones, circulating testosterone concentrations sometimes fall in response to stress (Ursin et al., 1978; Curtis, 1979; Rose, 1980), and also during lactate-induced panic (Appleby et al., 1981). However, LH and FSH changes in response to stress generally have not been observed (Ursin et al., 1978; Rosa, 1980), including no response to lactate in panic patients (Carr et al., 1986). Sex hormone fluctuations in women during the menstrual cycle may be related to changes in anxiety levels, although fluctuations have not always been observed (Golub, 1976; Abplanalp et al., 1977; Lahmeyer et al., 1982; Rubinow \& Roy-Byrne, 1984; Veith et al., 1984, Chamey \& Heninger, 1986a; Cameron et al., in press). Finally, pregnancy, possibly mediated by the associated endocrine changes, is associated with an improvement in panic anxiety (George et al., 1987).

To summarize the relationship between anxiety and the circulating concentrations of those pituitary hormones which have been studied: (a) ACTH and/or cortisol may be elevated in panic or generalized anxiety patients; (b) growth hormone shows an inconsistent pattern; (c) prolactin elevations may be specifically associated with panic anxiety; (d) thyroid axis abnormalities are probably associated with anxiety symptoms mainly during thyrotoxic states only; and (e) gonadal hormones, specifically testosterone, may be low in anxiety, while 
menstrual fluctuations in reports of anxiety severity may implicate other changes as well.

In addition to pituitary hormones, glucose and glucose regulatory hormones may be affected under some circumstances. Glucose (Hall \& Brown, 1979) and glucagon and insulin (Curtis, 1979) concentrations are responsive to stress, and insulin (but not glucagon) increases during phobic anxiety (Nesse et al., 1985a). However, insulin concentrations did not change during lactate-induced panic (Gorman et al., 1984b), and hypoglycemia is symptomatically different from panic attacks (Lader, 1981; Uhde et al., 1984b; Schweizer et al., 1986b; Cameron et al., 1988).

Melatonin, a product of the pineal gland which is under adrenergic control and which shows a large circadian variation, has been studied in panic patients. McIntyre et al. (1986) and Cameron et al. (1987) reported reductions in normal nighttime plasma melatonin concentrations. Plasma $\beta$-endorphin concentrations were elevated during phobic anxiety in a single simple phobic patient (Thyer \& Matthews, 1986), but not in response to lactate in panic patients (Carr et al., 1986).

Other circulating substances potentially related to hormonal activity also have been studied. Lactic acid was elevated in normal subjects under stress (Hall \& Brown, 1979), but not always in panic patients compared to normal subjects at rest (Nesse et al., 1984; Liebowitz et al., 1985; Carr et al., 1986). Exercise, however, does raise lactate more in people with anxiety than in normal subjects (Jones \& Mellersh, 1946; Cohen \& White, 1950; Holmgren \& Strom, 1959). Cyclic AMP levels were elevated in both normal and "neurotic" (anxious?) patients in response to stress (Moyes \& Moyes, 1977; Okada et al., 1983), although levels in panic patients were in the normal range (Nesse et al., 1984). The glucose regulatory and lactic acid abnormalities suggest a possible dysfunction of metabolic energy regulation (Cryer, 1984); systemic catecholamine abnormalities might be involved in this dysfunction.

Enzyme activity levels also have been studied. Platelet monoamine oxidase (MAO) activity is elevated in some anxious individuals (Davidson et al., 1980; Mathew et al., 1981a; Yu et al., 1982; Gorman et al., 1985); levels were reduced by relaxation training (Mathew et al., 1981a). However, one study reported decreases in MAO in anxious patients (Khan et al., 1986). Patients with panic attacks had elevated activity of MAO (Gorman et al., 1985). Dopamine-Bhydroxylase was normal in generalized anxiety patients (Mathew et al., 1981b; Friedman et al., 1984); it was reduced by relaxation (Mathew et al., 1981b). Catechol-0-methyl transferase (COMT) levels were normal in generalized anxiety patients, and no relaxation effect was observed (Mathew et al., 1980a). Low COMT levels were correlated with high levels of trait anxiety (Mathew et al., 1980c), and in another study (Shulman et al., 1978) patients with severe anxiety had higher levels than depressed patients. In that study (Shulman et al., 1978), however, agitation in depressed patients predicted high COMT levels in the depressed patients, suggesting that agitation rather than anxiety per se might account for the elevations observed in anxiety. Acetylcholinesterase was normal in generalized anxiety patients, while pseudocholinesterase was elevated; no relaxation effect was observed (Mathew et al., 1980b). Finally, B-thromboglobulin and platelet factor IV were reported to be elevated in panic patients (Sheehan et al., 1983a), although we did not observe this (unpublished data). Thus, monoamine oxidase levels appear to be abnormal; this might be associated with abnormalities in systemic catecholamine levels.

Elevations (Giannini et al., 1983; Davis et al., 1985) as well as decreases (Evans et al., 1985) of plasma serotonin, and decreased urinary 5-HIAA (Giannini et al., 1983), have been reported in small groups of anxious individuals. Platelet serotonin uptake has been reported to be abnormal in panic patients (Norman et al., 1986), but platelet serotonin levels were normal (Balon et al., 1987). Finally, plasma HVA, a metabolite of dopamine, was not significantly elevated in panic patients (Roy-Byme et al., 1986a); however, a bimodal distribution was observed, with the most anxious patients tending to have higher concentrations. 
TABLE II. PHYSIOLOGICAL FUNCTIONING IN ANXIETY DISORDERS

\begin{tabular}{|c|c|}
\hline Physiological Function & Status in Anxious Patients Compared to Normal Subjects \\
\hline Heart Rate & $\begin{array}{l}\text { Often increased during anxiety of all kinds; may be normal in anxiety } \\
\text { disorder patients when not acutely anxious }\end{array}$ \\
\hline Mitral Valve Prolapse & Probably increased frequency in panic patients \\
\hline $\begin{array}{l}\text { Diphasic Tachycardia - } \\
\text { Bradycardia Response }\end{array}$ & Present more frequently in BII phobic patients \\
\hline Blood Pressure & $\begin{array}{l}\text { Probably slightly increased } \\
\text { - primarily systolic; may show postural abnormalities }\end{array}$ \\
\hline Finger Pulse Volume & Decreased \\
\hline Forearm Blood Flow & Probably increased \\
\hline $\begin{array}{l}\text { Galvanic Skin Response (GSR) } \\
\text { (measure of sweating) }\end{array}$ & Increased \\
\hline $\begin{array}{l}\text { Electromyographically (EMG) } \\
\text { measured muscle activity }\end{array}$ & Increased (not in all muscle groups) \\
\hline Respiration & Increased (relationship to hyperventilation syndrome unresolved) \\
\hline Pupil Size & Less constriction \\
\hline Orienting Response & Inconsistent \\
\hline Salivation & Unchanged \\
\hline Urination and Defecation & Some increase \\
\hline Finger Tremor & Increased \\
\hline
\end{tabular}

\section{Autonomic and Cardiovascular Changes}

A wide variety of somatic symptoms have been associated with both normal and pathological anxiety; many of these reflect changes in the autonomic nervous system (Lader and Marks, 1971; Kelly, 1980; Cameron et al., 1986b). In a large study of "anxiety neurosis" (Wheeler et al., 1950), several autonomic symptoms including palpitations, breathlessness, chest pain, and paresthesias were experienced by at least $50 \%$ of the patients, with palpitations being most common of all symptoms reported. Concerning autonomic changes associated with anxiety, a number of physiological parameters have been studied, including heart rate and blood pressure, galvanic skin response, electromyographic changes, peripheral blood flow, respiration, salivation, pupil changes, body temperature, changes in hollow viscus activity including changes in urination and defecation, and the startle and orienting responses. Basal and stimulated levels of these parameters in both patients and normal subjects, as well as differences between patients and normals in habituation of these parameters, have been examined. Most studies have reported hyperactivation of these parameters in patients; however, both positive and negative results of studies of habitation, reactivity, and "spontaneous" variability have been reported. Furthermore, these changes do not necessarily correlate with each other or with subjective ratings of anxiety symptoms (Tyrer \& Lader, 1976; Morrow \& Labrum, 1978; Nesse et al., 1985a). Although changes in these variables in response to treatment have been reported (Lang et al., 1970; Lande, 1982), desynchrony of these changes during treatment sometimes has been observed (Grey et al., 1979; Andrasik et al., 1980; Barlow et al., 1980; McLeod et al., 1986).

The physiological findings are summarized in Table II. Heart rate was significantly elevated in anxious patients in comparison to normal subjects in most studies (Jones \& Mellersh, 1946; Tan, 1964; Wing, 1964; Kelly \& Walter, 1969; Bond et al., 1974; Freedman et al., 1984; Roth et al., 1986; Taylor et al., 1986; Shear et al., 1987), but not in all (Ackner, 
1956; Cameron et al., 1987; Mathew et al., 1980c; Mathew \& Wilson, 1986). Heart rate was significantly increased during both yohimbine-induced (Charney et al., 1987) and situational panic attacks (Woods et al., 1987). Anxious patients seem to be excessively aware of their own heart beat (Tyrer et al., 1980; Pyke \& Greenberg, 1986) and appear to tolerate exercise less well than normals, including becoming symptomatic during exercise (Cameron \& Hudson, 1986) and having a greater heart rate response to exercise (Crowe et al., 1979). Finally, a high resting heart rate may be associated with the later development of anxiety (Phillips et al., 1987).

Many of these and subsequent studies to be reviewed involved experimental procedures in which immediate situational variables (i.e., abnormal reactivity) might have contributed, at least partially, to observed differences. For example, in one study, although heart rate increases were associated with panic attacks, heart rates at other times throughout the day did not differ from normal subjects (Freedman et al., 1985). However, we found both panic anxiety patients who were "anxious" in anticipation of receiving isoproterenol and patients who were not anticipating any injection to have significantly and equally increased heart rates compared to normal subjects (unpublished data). Furthermore, heart rate increases are not always present even during panic attacks (Taylor et al., 1982; 1986; Freedman et al., 1985; Cameron et al., 1987). Differences in results between studies might represent different subpopulations of anxious patients, some who have prominent autonomic systems and some who do not (HoehnSaric \& McLeod, 1985). Although other cardiac abnormalities such as dysrhythmias also have been observed in anxious patients (Kannel et al., 1958; Levander-Lindgren, 1962; Shear, 1986; Shear et al., 1987; Cameron et al., 1987), similar abnormalities have been observed in healthy normal subjects as well (Brodsky et al., 1977, Sobatka et al., 1981).

Mitral valve prolapse is a specific cardiac abnormality which may be associated with panic anxiety (Crowe, 1985; Nesse et al., 1985b; Dager et al., 1986a; 1986b; Gorman et al., 1986b; Liberthson et al., 1986) and a variety of autonomic changes (Coghlan et al., 1979; DeCarvalho et al., 1979; Gaffney et al., 1979; 1983; Boudoulas et al., 1980; 1983; Clark et al., 1980; Pasternac et al., 1982; Puddu et al., 1983). This observation is further support for a possible association between anxiety and cardiac and autonomic abnormalities.

In summary, there is substantial cardiovascular symptomatology, and also evidence for cardiac dysfunction, in anxious people; hyperreactivity appears to be important. The meaning of the association between panic anxiety and mitral valve prolapse is not yet clear; it might reflect manifestations of an underlying autonomic dysfunction, although inconsistencies exist in the literature on whether panic patients with and without prolapse differ on measures of adrenergic activity (Nesse et al., 1985b; Dager et al., 1987).

Patients with blood, illness, and injury (BII) ("blood-injury" in DSM-III-R) phobia have an apparently specific cardiac function abnormality not seen in other anxious patients. The other patients usually have acute increases in heart rate in association with acute increases in anxiety, followed by retums to pre-anxiety baseline rates. However, BII phobics often show a biphasic cardiac response, with the acute tachycardia followed by a significant bradycardia and associated fall in blood pressure, often leading to actual vasovagal fainting in these patients; this is seen much less often in people with other anxiety disorders (Curtis \& Thyer, 1983; Ost et al., 1984). Thus, this may be a qualitatively distinct group.

Vascular as well as cardiac changes have been studied in anxious patients. Blood pressure is significantly elevated compared to normal subjects (Innes et al., 1959; Kelly, 1980; Nesse et al., 1985a, Mathew \& Wilson, 1986), although the increase is small, not always significant, and not always observed (Cameron et al., unpublished data); systolic increases tend to be greater than diastolic. Some variability in response to postural change also has been observed (Nesse et al., 1984). Blood pressure response to a cold pressor test was the same in panic anxiety patients and normal subjects (Grunhaus et al., 1983), but greater in panic patients in response to 
yohimbine (Charney et al., 1984; 1987a), and less in response to clonidine (Charney \& Heninger, 1986a; Nutt, 1986). No significant blood pressure changes have been observed during situational panic (Woods et al., 1987), and neither blood pressure nor heart rate prior to infusion is a good predictor of who will have a lactate-induced panic attack (Cowley et al., 1987; Yeragani et al., 1987).

Finger pulse volume and forearm blood flow are different in anxious patients than in normals (Ackner, 1956; Kelly, 1966; 1980; Kelly \& Walter, 1969); changes associated with acute anxiety also have been observed (Lader \& Mathews, 1970). Forearm blood flow probably is increased (Jones \& Mellersh, 1946; Kelly, 1966; Kelly \& Walter, 1969), although one study did not find an increase (Harper et al., 1965); pulse volume (Ackner, 1956) and finger temperature, a variable which might be expected to correlate positively with pulse volume (Freedman et al., 1984), are decreased. These observations are consistent with peripheral vasoconstriction associated with dilation of more central vessels, as well as with increased heart rate. On the other hand, the reported blood pressure elevations are more consistent with systemic vasoconstriction.

Galvanic skin response (GSR) is a measure of sweating. GSR and related measures have demonstrated increased sweating in anxious patients in most (Wing, 1964; Bond et al., 1974; Maple et al., 1982, Quinton, 1983; Roth et al., 1986) but not all (Ackner, 1956; Freedman et al., 1984) studies; abnormalities in social phobics also have been reported (Dimberg et al., 1986). Increases associated with acute anxiety (Lader \& Mathews, 1970) and impaired habituation to repeated stimuli (Raskin, 1975) have been seen. Increased "spontaneous" fluctuations also have been reported (Lader, 1967; Chattapadhyay et al., 1980). These data are in agreement with clinical observations of increased sweating associated with anxiety; $45 \%$ of patients in one large study reported this symptom (Wheeler et al., 1950). Sweating associated with emotional stress (anxiety?) is usually axillary, palmar, or plantar, this distribution is different than sweating which occurs under other circumstances and suggests a qualitative, possibly centrally mediated, difference between emotional and other stimuli for sweating (Quinton, 1983).

Electromyographic (EMG) activity is increased in anxious individuals (Sainsbury \& Gibson, 1954; Goldstein, 1964; Wing, 1964), and increases further in association with acute anxiety in some anxious people (Lader \& Mathews, 1970). Reactivity studies have produced conflicting results (Goldstein, 1964; Wing, 1964). The findings varied among the muscle groups tested, and patients with different symptom patterns had different muscle tension patterns (Sainsbury \& Gibson, 1954). Negative findings concerning differences between patients and normals also have been reported (Lader \& Wing, 1966).

Respiratory changes, including the "hyperventilation syndrome," are associated with anxiety (Jones \& Mellersh, 1946; Coppen \& Mezey; 1960, Goldstein, 1964; Lum, 1975; 1976; Missri \& Alexander, 1978; Compernolle et al., 1979; Magarian, 1982; Pincus \& Tucker, 1985; Bass et al., 1983; Bass \& Gardner, 1985; Clark, 1986). Patients tend to breathe faster and less efficiently than normal subjects. This agrees with the frequent clinical complaints of respiratory problems such as "breathlessness" in anxious patients (Wheeler et al., 1950). The status of the hyperventilation syndrome vis-a-vis primary anxiety is not clear. The large overlap in symptom profiles suggests that many patients in these two groups actually have the same disorder; however, some patients with primary hyperventilation may exist. Furthermore, it is not clear whether hyperventilation in primary anxiety patients is a physiological abnormality directly associated with the primary anxiety disorder or a secondary psychophysiological reaction to anxiety; it may be both - different in different patients or in the same patient at different times. Panic patients do not have a different ventilatory response to $\mathrm{CO}_{2}$ inhalation than do normal subjects (Woods et al., 1986). In one study (Gorman et al., 1984a), only $25 \%$ of panic patients had panic attacks in response to hyperventilation of room 
air; nevertheless, the same group of investigators reported evidence that panic patients are chronic hyperventilators (Gorman et al., 1986a).

Physiological functions other than those reviewed above have been studied in anxious patients (Lader \& Marks, 1971). Data in these other areas are less complete or detailed and therefore will be mentioned only briefly. Pupil size is less constricted (Bond et al., 1974), orienting responses are inconsistent (Tan, 1964; Lader \& Wing, 1966; Bond et al., 1974, Orr \& Pitman, 1987), salivation is unchanged (Lader \& Marks, 1971), the urge to urinate and/or defecate is sometimes increased (Wheeler et al., 1950), and finger tremor is increased (Lader, 1975) in anxious people.

In summary, there is substantial evidence for autonomic nervous system dysfunction in people with anxiety disorders; most consistent has been adrenergic hyperactivity. However, like catecholamines (an adrenergic correlate) and other endocrine data, significant inconsistencies are apparent. The reasons for these inconsistencies are unknown; they may relate to differences in reactivity and habituation, different subpopulations of patients, and/or low correlations between physiological changes and reports of subjective symptoms.

\section{Peripheral Receptor Status}

Only a few studies have examined peripheral receptor status in patients with anxiety disorders. Platelet $\alpha_{2}$-adrenoreceptors (maximum number of binding sites $-B \max$ ) are decreased in patients with panic attacks compared to both normal subjects and depressives when yohimbine is the assay ligand; when clonidine is used as the ligand, both normals and patients with panic have fewer $\alpha_{2}$-receptors than depressives, while panic patients may or may not be different than normals (Cameron et al., 1984; unpublished data). Binding of dihydroergocriptine, a nonspecific $\alpha$-adrenoreceptor ligand, was reported to be increased in panic patients (Roy-Byrne \& Uhde, 1985), and another group of investigators did not replicate the decrease in yohimbine binding (Nutt \& Fraser, 1987); the reason for this discrepancy is not known.

Normal peripheral adrenergic receptor function in panic patients is suggested by identical blood pressure and prolactin responses to a cold-pressor test in controls and patients (Grunhaus et al., 1983). However, B-receptor responsiveness was decreased in patients with panic attacks when assessed by heart rate responses to graded doses of intravenous isoproterenol (Nesse et al., 1984) and isoproterenol-stimulated cyclic AMP from lymphocytes (Lima \& Turner, 1983). Receptor down-regulation is consistent with the elevated plasma and urinary catecholamine concentrations often reported in panic disorder patients (Ballenger et al., 1984; Cameron et al., 1984; Nesse et al., 1984; 1985a). Generalized anxiety patients have trends toward decreases in clonidine binding and yohimbine binding in comparison to normals (Cameron et al., unpublished data).

Imipramine binding to platelets, a putative measure of the serotonin uptake site, appears to be normal (Davis et al., 1985; Roy-Byme \& Uhde, 1985; Nutt \& Fraser, 1987; Schneider et al., 1987; Uhde et al., 1987). Normal opiate receptor function is suggested by studies in which panic patients had responses to naloxone that were minimal and identical to those of control subjects (Hoehn-Saric \& Masek, 1981; Liebowitz et al., 1984). However, there may be an abnormality in people with obsessive-impulsive disorder (Insel \& Pickar, 1983). These data may be more relevant for central than peripheral receptor status; the relationship between peripheral and central receptor status is not always clear, and the relevance of peripheral receptors for the pathophysiology of a centrally mediated state such as anxiety must be considered.

Direct assay of benzodiazepine receptors or benzodiazepine receptor ligands in anxious patients is a promising strategy, although relevant peripheral receptor sources may not be readily available. Rats selectively bred for "emotionality" (anxiety?) have fewer numbers of 
brain benzodiazepine receptors than normal rats (Robertson, 1979), and [11C]-R0-15-1788, a positron-emitting benzodiazepine receptor antagonist, was specifically bound to brain (cerebral and cerebellar cortices and basal nuclei) receptors in monkeys and humans (Persson et al., 1985).

\section{DISCUSSION}

The most consistent finding of the research reviewed above is the association of anxiety with activation of the adrenergic limb of the autonomic nervous system, as supported by (a) endocrine findings (elevated catecholamines and, possibly, monoamine oxidase abnormalities, glucose metabolic and lactate abnormalities, and the.similarity between anxious and thyrotoxic symptoms); (b) physiological findings (heart rate, blood pressure, galvanic skin response, and respiratory abnormalities, as well as the association of panic anxiety with mitral valve prolapse); and (c) adrenergic receptor abnormalities. Nevertheless, adrenergic activation has not always been observed, and adrenergic symptoms (e.g., heart rate increase) have not always been strongly correlated with associated physiological changes. Parasympathetic symptoms and physiological abnormalities occurred less frequently. This pattern is similar to that seen during stress in normal individuals.

Other potential psychobiological changes also have been studied, mainly in endocrine systems associated with hypothalamic-pituitary regulation. Abnormal activity in several of these systems has been observed, but results are often mixed or too preliminary to allow specific conclusions. One exception is the normal rate of DST abnormalities in people with panic attacks.

As noted above, a major justification for studying endocrine and physiological changes is that these changes might permit inferences about associated changes in the central nervous system. Might the changes thus far observed allow any such inferences? Since peripheral adrenergic changes are the most consistent abnormalities reported, it seems very likely that dysfunction of central control of the peripheral adrenergic system is involved in the pathophysiology of anxiety disorders.

Electrical stimulation of the locus ceruleus in monkeys causes a reaction that seems similar to fear (anxiety?) (Redmond, 1979). The locus ceruleus, which is located adjacent to the aqueduct in the dorsal pons and has many efferents including some to the amygdala, cingulate, and hippocampus, is the source of more than $50 \%$ of all the norepinephrine in the brain, and most of the cell bodies of the remaining noradrenaline neurons are close by (Redmond, 1979, Ziegler \& Lake, 1984). The cortex (especially prefrontal and cingulate), the limbic system (especially the amygdala), and the hypothalamus all have been implicated in the central control of autonomic responses to stress or anxiety (Brooks et al., 1979; Galosy et al., 1981; Mancia \& Zanchetti, 1981; Brezinoff \& Guiliano, 1982; Randall \& Hasson, 1982; Anderson, 1984; Herd, 1984; Randall, 1984; Smith \& DeVito, 1984; Verrier \& Lown, 1984). Furthermore, central and peripheral autonomic activity are associated (Maas \& Leckman, 1983; Svensson, 1987). Challenge tests with yohimbine, a centrally active adrenergic agent, produce anxiety in susceptible individuals (Charney et al., 1983; 1984; 1987a). Thus, there is support for the involvement of central noradrenergic pathways in the genesis of anxiety, and also for the involvement of these pathways in control of the peripheral autonomic reactions.

However, treatment with adrenergically active drugs has produced at best limited support for the involvement of central adrenergic mechanisms in anxiety. B-adrenergic antagonists such as propranolol seem to be useful mainly for the peripheral adrenergic symptoms of anxiety (Cole, 1984; Noyes, 1985), and rapid tolerance develops to the anxiolytic effects of clonidine, an $\alpha_{2}$-adrenoceptor agonist (Hoehn-Saric et al., 1981; Liebowitz et al., 1981). And, buspirone, a new anxiolytic drug for generalized anxiety (and panic?) stimulates locus ceruleus firing and 
(Sanghera \& German, 1983; Sanghera et al., 1983). Finally, although peripheral adrenergic $\alpha_{2}$ B-adrenoreceptors are abnormal in anxious patients, this abnormality may only reflect changes in peripheral status and not necessarily central changes. Thus, the evidence for the involvement of central noradrenergic systems in anxiety disorders should be considered tentative at this time. The potential involvement of other central nervous system pathways which are involved in the production of anxiety, including the peripheral adrenergic symptoms, should be further explored.

Patterns of hypothalamic-pituitary hormonal change might permit inferences about neurotransmitters involved in anxiety in this brain region (Checkley, 1980; Elias et al., 1982; Frohmann \& Berelowitz, 1984; Reichlin, 1985; Tuomisto \& Männistö, 1985), but the results are not yet extensive or consistent enough to allow specific inferences. However, the results of one study (Cameron et al., 1987) have suggested that GABA might be involved. This observation would be consistent with research relating GABA, the benzodiazepines, and anxiety.

Benzodiazepines, which are effective anxiolytic agents (Rickels, 1981), appear to function through a GABA "macromolecular receptor complex" (Paul et al., 1981; Paul \& Skolnick, 1984); B-carbolines, GABA "inverse agonists," are potent inducers of anxiety in humans (Dorow et al., 1983); and caffeine, which also produces anxiety in susceptible individuals (Uhde et al., 1984a, Charney et al., 1985; Lee et al., 1985), may interact with the GABA receptor either directly or through adenosine receptors (Snyder \& Sklar, 1984; Marangos \& Boulenger, 1985). However, the pharmacology of buspirone is not fully consistent with the assumed mechanisms of action of GABA and the benzodiazepines on anxiety (Eison \& Temple, 1986). Other neurotransmitters have also been implicated, especially serotonin and possibly dopamine (Braestrap, 1982; Hoehn-Saric, 1982; Judd et al., 1985; Eison \& Temple, 1986), however, their details are less well understood.

As described above, even though some conclusions seemed to be justified, many of the observations made in the research reviewed were either inconclusive, too preliminary for firm acceptance, or contradicted by other observations. As future research seeks to clarify these ambiguities, several sources of potential variability in outcome should be considered: (a) individual subject differences (including demographics, age, sex, etc.), and differences between diagnostic groups within the overall designation of "anxiety disorder"; (b) reactivity and habituation factors, which might differ between anxious individuals and normal subjects (e.g., the difference between resting and non-resting state); (c) potential variance between physiological changes and patient reports of subjective symptomatology; (d) lack of correlation among the various physiological/hormonal changes, including the desynchrony of changes sometimes observed during treatment; (e) the difference between observations in the periphery and the central nervous system (e.g., what correlations can be expected between peripheral receptors or peripheral autonomic functioning and central neurotransmitter function); (f) to what extent results of studies which used pharmacological challenges are due to anxiety induction vs. direct pharmacologic effects, as well as the issue of whether differences in such studies between anxious individuals and normals are qualitative vs. quantitative; and (g) whether the pathophysiological changes observed are directly related to etiology vs. being only indirectly involved (e.g., as "upstream" or "downstream" effects). Two other issues of importance are: (a) what knowledge about the pathophysiology of anxiety can be obtained from observations about effective treatment methods, including the observation that nonpharmacologic methods can modify the physiological anxiety response; and (b) as noted above, what the psychobiological relationship is between anxiety disorders and stress in normal subjects, and correlatively, is the stress response different in anxious individuals? In other words, are the psychobiology of stress in normal persons and the psychobiology of anxiety reactions in patients with anxiety disorders really different? One hypothesis which seems to be 
consistent with many of the observed data is that the "switch" or "trigger" which sets off an anxiety reaction is different, at least quantitatively and probably also qualitatively, in people with anxiety disorders vs. stress ("anxiety") in normals, but that once a reaction occurs, the psychophysiological symptoms are fairly similar (even though the pattern of hormonal response, especially epinephrine, may be different). A systematic inquiry into the psychobiology of anxiety disorders will need to attend to all these issues.

\section{REFERENCES}

Abplanalp JM, Livingston L, Rose RM, Sundwisch D (1977) Cortisol and growth hormone responses to psychological stress during the menstrual cycle. Psychosom Med 39: 158-177.

Ackner B (1956) The relationship between anxiety and the level of peripheral vasomotor activity. $J$ Psychosom Res 1: 21-48.

American Psychiatric Association (1980) Diagnostic and Statistical Manual of Mental Disorders, Third Edition. American Psychiatric Association, Washington DC, pp 225-239.

American Psychiatric Association (1987) Diagnostic and Statistical Manual of Mental Disorders, Third Edition, Revised. American Psychiatric Association, Washington DC, pp 235-253.

Anderson DE (1984) Interactions of stress, salt, and blood pressure. Annu Rev Physiol 46: 143-153.

Andrasik F, Turner SM, Ollendick TH (1980) Self-report and physiologic responding during an vivo flooding. Behav Res Ther 18: 593-595.

Appleby JS, Klein DF, Sachar EJ, Levitt M (1981) Biochemical indices of lactate induced panic: a preliminary report. In: Klein DF, Rabkin JG (Eds) Anxiety: New Research and Changing Concepts. Raven Press, New York, pp 411-423.

Avery DH, Osgood TB, Ishiki DM, Wilson LG, Kenny M, Dunner DL (1985) The DST in psychiatric outpatients with generalized anxiety disorder, panic disorder, or primary affective disorder. $A m J$ Psychiatry 142: 844-848.

Axelrod J, Reisine TD (1984) Stress hormones: their interaction and regulation. Science 224: 452-459.

Ballenger JC, Peterson GA, Laraia M, Hudek A, Lake CR, Jimerson D, Cox DJ, Trockman C, Shipe JR, Wilkinson C (1984) A study of plasma catecholamines in agoraphobia and the relationship of serum tricyclic levels to treatment response. In: Ballenger JC (Ed) Biology of Agoraphobia. American Psychiatric Press, Washington DC, pp 27-63.

Balon R, Pohl R, Yeragani V, Rainey J, Oxenkrug GF (1987) Platelet serotonin levels in panic disorder. Acta Psychiatr Scand 75: 315-317.

Barlow DH, Mavissakalian MR, Schofield LD (1980) Patterns of desynchrony in agoraphobia: a preliminary report. Behav Res Ther 18: 441-448.

Bass C, Cawley R, Wade C, Ryan KC, Gardner WN, Hutchinson DCS, Jackson G (1983) Unexplained breathlessness and psychiatric morbidity in patients with normal and abnormal coronary arteries. Lancet $\mathrm{i}$ : 605-609.

Bass C, Gardner W (1985) Emotional influences on breathing and breathlessness. J Psychosom Res 2: 599-609.

Bond AJ, James DC, Lader MH (1974) Physiological and psychological measures in anxious patients. Psychol Med 4: 364-373.

Boudoulas H, Reynolds JC, Mazzaferri E, Wooley CF (1980) Metabolic studies in mitral valve prolapse syndrome: a neuroendocrine-cardiovascular process. Circulation 61: 1200-1205.

Boudoulas H, Reynolds JC, Mazzaferri E, Wooley CF (1983) Mitral valve prolapse syndrome: the effect of adrenergic stimulation. J Am Coll Cardiol 2: 638-644.

Braestrap C (1982) Anxiety. Lancet ii: 1030-1034.

Brezinoff HE, Guiliano R (1982) Cardiovascular control by cholinergic mechanisms in the central nervous system. Annu Rev Pharmacol Toxicol 22: 341-381.

Bridges M, Yeragani VK, Rainey JM, Pohl R (1986) Dexamethasone suppression test in patients with panic attacks. Biol Psychiatry 21: 849-853.

Brodsky M, Wu O, Denes P, Kanakis C, Rosen KM (1977) Arrhythmias documented by 24-hour continuous electrocardiographic monitoring in $\mathbf{5 0}$ male medical students without apparent heart disease. Am J Cardiol 39: 390-395.

Brooks CM, Koizumi K, Soto A (1979) Integrative Functions of the Autonomic Nervous System. University of Tokyo Press/Elsevier North-Holland, Tokyo. 
Cameron OG, Hudson CJ (1986) Influence of exercise on anxiety level in patients with anxiety disorders. Psychosomatics 27: 720-723.

Cameron OG, Smith CB, Hollingsworth PJ, Nesse RM, Curtis GC (1984) Platelet alpha ${ }_{2}$-adrenergic receptor binding and plasma catecholamines. Arch Gen Psychiatry 41: 1144-1148.

Cameron OG, Kerber K, Curtis GC (1986a) Obsessive-compulsive disorder and the DST. Psychiatry Res 19: 329-330.

Cameron OG, Thyer BA, Nesse RM, Curtis GC (1986b) Symptom profiles of patients with DSM-III anxiety disorders. Am J Psychiatry 143: 1132-1137.

Cameron OG, Lee MA, Curtis GC, McCann DS (1987) Endocrine and physiological changes during "spontaneous" panic attacks. Psychoneuroendocrinology 12: 321-331.

Cameron OG, Buzan R, McCann DS, Schteingart DE (1988) Symptoms of insulin-induced hypoglycemia in normal subjects. $J$ Psychosom Res 32: 41-49.

Cameron OG, Kuttesch D, McPhee KM, Curtis GC (in press) Menstrual fluctuation in the symptoms of panic anxiety. J Affect Disord.

Carr DB, Sheehan DV, Surman OF, Coleman JH, Greenblatt DJ, Heninger GR, Jones KJ, Levine PH, Watkins WD (1986) Neuroendocrine correlates of lactate-induced anxiety and their response to chronic alprazolam therapy. Am J Psychiatry 143: 483-494.

Charney DS, Heninger GR (1985a) Noradrenergic function and the mechanisms of action of antianxiety treatment: I. The effect of long-term alprazolam treatment. Arch Gen Psychiatry 42: 458-467.

Charney DS, Heninger GR (1985b) Noradrenergic function and the mechanism of action of antianxiety treatment: II. The effect of long-term imipramine treatment. Arch Gen Psychiatry 42: 473-481.

Charney DS, Heninger GR (1986a) Abnormal regulation of noradrenergic function in panic disorders. Arch Gen Psychiatry 43: 1042-1054.

Charney DS, Heninger GR (1986b) Serotonin function in panic disorders. Arch Gen Psychiatry 43: 1059-1065.

Charney DS, Heninger GR, Redmond DE (1983) Yohimbine induced anxiety and increased noradrenergic function in humans: effects of diazepam and clonidine. Life Sci 33: 19-29.

Charney DS, Heninger GR, Breier A (1984) Noradrenergic function in panic anxiety. Arch Gen Psychiatry 41: 751-763.

Charney DS, Heninger GR, Jatlow PI (1985) Increased anxiogenic effects of caffeine in panic disorders. Arch Gen Psychiatry 42: 233-243.

Charney DS, Woods SW, Goodman WK, Heninger GR (1987a) Neurobiological mechanisms of panic anxiety: biochemical and behavioral correlates of yohimbine-induced panic attacks. Am J Psychiatry 144: 10301036.

Charney DS, Woods SW, Goodman WK, Heninger GR (1987b) Serotonin function in anxiety. II. Effects of the serotonin agonist MCPP in panic disorder patients and healthy subjects. Psychopharmacology 92: 14-24.

Chattapadhyay P, Cooke E, Toone B, Lader M (1980) Habituation of physiological responses in anxiety. Biol Psychiatry 15: 711-721.

Checkley SA (1980) Neuroendocrine tests of monoamine function in man: a review of basic theory and its application to the study of depressive illness. Psychol Med 10: 35-53.

Chosy JJ, Lewis WC, Graham DT (1970) Phobia questionnaire responses and urine catecholamines. Arch Gen Psychiatry 22: 58-62.

Clark DM (1986) A cognitive approach to panic. Behav Res Therap 24: 461-470.

Clark RW, Boudoulas H, Schaal SF, Schmidt HS (1980) Adrenergic hyperactivity and cardiac abnormality in primary disorders of sleep. Neurology 30: 113-119.

Coghlan HC, Phares P, Cowley M, Copley D, James TN (1979) Dysautonomia in mitral valve prolapse. Am J Med 67: 236-244.

Cohen ME, White PD (1950) Life situations, emotions, and neurocirculatory asthenia (anxiety neurosis, neurasthenia, effort syndrome). Res Publ Assoc Nerv Ment Dis 29: 832-869.

Cole JO (1984) B-adrenergic blockers and buspirone. In: Grinspoon L (Ed) Psychiatric Update, Vol III. American Psychiatric Press, Washington, DC, pp 490-503.

Compernolle T, Hoogduin K, Joele L (1979) Diagnosis and treatment of the hyperventilation syndrome. Psychosomatics 20: 612-625.

Coppen AJ, Mezey AG (1960) The influence of sodium amytal on the respiratory abnormalities of anxious psychiatric patients. J Psychosom Res 5: 52-55.

Cowley DS, Hyde TS, Dager SR, Dunner DL (1987) Lactate infusions: the role of baseline anxiety. Psychiatry Res 21: 169-179.

Crowe RR (1985) Mitral valve prolapse and panic disorder. In: Curtis GC, Thyer BA, Rainey DM (Eds) Psychiatric Clinics of North America: Anxiety Disorders 8(1): 63-71. 
Crowe RR, Pauls DL, Venkatesh A, Van Valkenberg C, Noyes R, Martins JB, Kerber RE (1979) Exercise and anxiety neurosis. Arch Gen Psychiatry 36: 652-653.

Cryer PE (1984) The sympathoadrenal system in human glucose counterregulation and diabetes mellitus. In: Ziegler MG, Lake CR (Eds) Norepinephrine. Williams and Wilkins, Baltimore, pp 471-485.

Curtis GC (1979) Psychoendocrine stress response: Steroid and peptide hormones. In: Stoll BA (Ed) Mind and Cancer Prognosis. Wiley, New York, pp 61-72.

Curtis GC, Thyer BA (1983) Fainting on exposure to phobic stimuli. Am J Psychiatry 140: 771-774.

Curtis GC, Nesse R, Buxton M, Lippman D (1978) Anxiety and plasma cortisol at the crest of the circadian cycle: reappraisal of a classical hypothesis. Psychosom Med 40: 368-378.

Curtis GC, Nesse R, Buxton M, Lippman D (1979) Plasma growth hormone: effect of anxiety during flooding in vivo. Am J Psychiatry 136: 410-414.

Curtis GC, Cameron OG, Nesse RM (1982) The dexamethasone suppression test in panic disorder and agoraphobia. Am J Psychiatry 139: 1043-1045.

Curtis G, Buxton M, Lippman D, Nesse R, Wright J (1976) "Flooding in vivo" during the circadian phase of minimal cortisol secretion: anxiety and therapeutic success without adrenal cortical activation. Biol Psychiatry 11: 101-107.

Dager SR, Comess KA, Dunner DL (1986a) Differentiation of anxious patients by two dimensional echocardiographic evaluation of the mitral valve. Am J Psychiatry 143: 533-535.

Dager SR, Comess KA, Saal AK, Dunner D (1986b) Mitral valve prolapse in a psychiatric setting: diagnostic assessment, research and clinical implications. Integr Psychiatry 4: 211-223.

Dager SR, Khan A, Comess KA, Raisys V, Dunner DL (1987) Mitral valve abnormalities and catecholamine activity in anxious patients. Psychiatry Res 20: 13-18.

Davidson J, Turnbull CP, Miller RD (1980) A comparison of inpatients with primary unipolar depression and depression secondary to anxiety. Acta Psychiatr Scand 61: 377-386.

Davis DP, Dunlap SR, Shear P, Brittain H, Hendrie H (1985) Biological stress responses in high and low trait anxious students. Biol Psychiatry 20: 843-851.

DeCarvalho JGR, Messerli FH, Frohlich ED (1979) Mitral valve prolapse and borderline hypertension. Hypertension 1: 518-522.

Dimberg U, Fredrikson M, Lundquist O (1986) Autonomic reactions to social and neutral stimuli in subjects high and low in public speaking fear. Biol Psychol 23: 223-233.

Dorow R, Horawski R, Paschelke G, Amin M, Braestrup C (1983) Severe anxiety induced by FG 7142, a betacarboline ligand for benzodiazepine receptors. Lancet ii: 98-99.

Eison AS, Temple DL (1986) Buspirone: review of its pharmacology and current perspectives on its mechanism of action. Am J Med 80(suppl 3B): 1-9.

Elias AN, Valenta LJ, Szckeres AV, Grossman MK (1982) Regulatory role of gamma-aminobutyric acid in pituitary hormone secretion. Psychoneuroendocrinology 7: 15-30.

Evans L, Schneider P, Ross-Lee L, Wittsheri B, Eadie M, Kenardy J, Hoey H (1985) Plasma serotonin levels in agoraphobia. Am J Psychiatry 142: 267.

Frankenhaeuser M (1971) Behavior and circulatory catecholamines. Brain Res 31: 241-262.

Fredrikson M, Sundin O, Frankenhaeuser M (1985) Cortisol excretion during the defense reaction in humans, Psychosom Med 47: 313-319.

Freedman RR, Ianni P, Ettedgui E, Pohl R, Rainey JM (1984) Psychophysiological factors in panic disorder. Psychopathology 17(suppl 1): 66-73.

Freedman RR, Ianni P, Ettedgui E, Puthenbath N (1985) Ambulatory monitoring of panic disorder. Arch Gen Psychiatry 42: 244-248.

Friedman MJ, Stolk JM, Harris PQ, Cooper TB (1984) Serum dopamine-B-hydroxylase activity in depression and anxiety. Biol Psychiatry 19: 557-570.

Frohmann LA, Berelowitz M (1984) The physiological and pharmacological control of anterior pituitary hormone secretion. In: Nemeroff CB, Dunn AH (Eds) Peptides, Hormones and Behavior. Spectrum, New York, pp 119-172.

Gaffney FA, Karlsson ES, Campbell W, Schutte JE, Nixon JV, Willerson JT, Blomquist CG (1979) Autonomic dysfunction in women with mitral valve prolapse syndrome. Circulation 59: 894-901.

Gaffney FA, Bastian BC, Lane LB, Taylor WF, Horton J, Schutte JE, Graham RM, Pettinger N, Blomquist CG (1983) Abnormal cardiovascular regulation in the mitral valve prolapse syndrome. Am J Cardiol 52: 316320.

Galosy RA, Clarke LK, Vasko MR, Crawford IL (1981) Neurophysiology and neuropharmacology of cardiovascular regulation and stress. Neurosci Biobehav Rev 5: 137-175.

George DT, Ladenheim JA, Nutt DJ (1987) Effect of pregnancy on panic attacks. Am J Psychiatry 14: 1078-1079. 
Giannini AJ, Castellani S, Dvoredsky AE (1983) Anxiety states: relationship to atmospheric cations and serotonin. J Clin Psychiatry 44: 262-264.

Goldstein IB (1964) Physiologic responses in anxious women patients. A study of autonomic activity and muscle tension. Arch Gen Psychiatry 10: 382-388.

Golub S (1976) The magnitude of premenstrual anxiety and depression. Psychosom Med 38: 4-12.

Gorman JM, Askanazi J, Liebowitz MR, Fyer AJ, Stein J, Kinney JM, Klein DF (1984a) Response to hyperventilation in a group of patients with panic disorder. Am J Psychiatry 141: 857-861.

Gorman JM, Liebowitz MR, Stein J, Fyer AJ, Klein DF (1984b) Insulin levels during lactate infusion. Am J Psychiatry 141: 1621-1622.

Gorman J, Liebowitz MR, Fyer AJ, Levitt M, Baron M, Davies S, Klein DF (1985) Platelet monoamine oxidase activity in patients with panic disorder. Biol Psychiatry 20: 852-857.

Gorman JM, Cohen BS, Liebowitz MR, Fyer AJ, Ross D, Davies SO, Klein DF (1986a) Blood gas changes and hypophosphatemia in lactate-induced panic. Arch Gen Psychiatry 43: 1067-1071.

Gorman JM, Shear MK, Devereux RB, King DL, Klein DF (1986b) Prevalence of mitral valve prolapse in panic disorder: effect of echocardiographic criteria. Psychosom Med 48: 167-171.

Grey S, Sartory G, Rachman S (1979) Synchronous and desynchronous changes during fear reduction. Behav Res Ther 17: 137-147.

Grunhaus L, Gloger S, Birmacher B, Palmer C, Ben-David M (1983) Prolactin response to the cold pressor test in patients with panic attacks. Psychiatry Res 8: 171-177.

Hall JB, Brown DA (1979) Plasma glucose and lactic acid alterations in response to a stressful exam. Biol Psychol 8: 179-188.

Hamlin CL, Lydiard RB, Martin D, Dackis CA, Pottash AC, Sweeney D, Gold MS (1983) Urinary excretion of noradrenaline metabolite decreased in panic disorder. Lancet ii: 740-741.

Harper M, Gurney C, Savage RD, Roth M (1965) Forearm blood flow in normal subjects and patients with phobic anxiety states. BrJ Psychiatry 111: 723-731.

Herd JA (1984) Cardiovascular response to stress in man. Annu Rev Physiol 46: 177-185.

Hoehn-Saric R (1982) Neurotransmitters in anxiety. Arch Gen Psychiatry 39: 735-742.

Hoehn-Saric R, Masek BJ (1981) Effects of naloxone on normals and chronically anxious patients. Biol Psychiatry 16: 1041-1050.

Hoehn-Saric R, McLeod DR (1985) Generalized anxiety disorder. In: Curtis GC, Thyer BA, Rainey JM (Eds) Psychiatric Clinics of North America: Anxiety Disorders 8(1): 73-88.

Hoehn-Saric R, Merchant A, Keyser M, Smith VK (1981) Effects of clonidine on anxiety disorders. Arch Gen Psychiatry 38: 1278-1282.

Holmgren A, Strom G (1959) Blood lactate concentration in relation to absolute and relative work load in normal men, and in mitral stenosis, atrial systolic defect, and vasoregulatory asthenia. Acta Med Scand 163: 185-193.

Holsboer F, von Bardeleben U, Buller R, Heuser I, Steiger A (in press) Stimulation response to corticotropinreleasing hormone $(\mathrm{CRH})$ in patients with depression, alcoholism and panic disorder. Horm Metabol Res.

Innes G, Millar M, Valentine M (1959) Emotion and blood pressure. J Ment Sci 105: 840-851.

Insel TR, Pickar D (1983) Naloxone administration in obsessive-compulsive disorder: report of two cases. Am $J$ Psychiatry 140: 1219-1220.

Jones M, Mellersh V (1946) A comparison of the exercise response in anxiety states and normal controls. Psychosom Med 8: 180-187.

Judd FK, Burrows GD, Norman TR (1985) The biological basis of anxiety: an overview. J Affect Disord 9: 271-284.

Kannel WB, Dawber TR, Cohen E (1958) The electrocardiogram in neurocirculatory asthenia (anxiety, neurosis or neurasthenia). A study of 203 neurocirculatory asthenia patients and 757 healthy controls in the Framingham study. Ann Int Med 49: 1351-1360.

Katerndahl DA, Vande Creek L (1983) Hyperthyroidism and panic attacks. Psychosomatics 24: 491-496.

Kathol RG, Turner R, Delahunt J (1986) Depression and anxiety associated with hyperthyroidism: response to antithyroid therapy. Psychosomatics 27: 501-505.

Kelly D (1966) Measurement of anxiety by forearm blood flow. Br J Psychiatry 112: 789-798.

Kelly D (1980) Anxiety and Emotions: Physiological Basis and Treatment. Charles C. Thomas, Springfield IL.

Kelly D, Walter CJS (1969) A clinical and physiological relationship between anxiety and depression. $B r J$ Psychiatry 115: 401-406.

Khan A, Lee E, Dager S, Hyde T, Raisys V, Avery D, Dunner D (1986) Platelet MAO-B activity in anxiety and depression. Biol Psychiatry 21: 847-849.

Ko GN, Elsworth JP, Roth RH, Rifkin BG, Leigh H, Redmond DE (1983) Panic induced elevation of plasma MHPG levels in phobic-anxious patients. Arch Gen Psychiatry 40: 425-430. 
Lader MH (1967) Palmar skin conductance measures in anxiety and phobic states. J Psychosom Res 11: 271-281.

Lader M (1975) The Psychophysiology of Mental Illness. Routledge and Kegan Paul, London.

Lader MH (1981) Assessment methods and the differential diagnosis of anxiety. J Clin Psychopharmacol 1: 342-349.

Lader M (1982) Biological differentiation of anxiety, arousal, and stress. In: Mathew RJ (Ed) The Biology of Anxiety. Brunner/Mazel, New York, pp 11-22.

Lader M, Marks I (1971) Clinical Anxiety. William Heinemann, London.

Lader M, Mathews A (1970) Physiological changes during spontaneous panic attacks. J Psychosom Res 14: 377-382.

Lader MH, Wing L (1966) Physiological Measures, Sedative Drugs, and Morbid Anxiety. Oxford University Press, London.

Lahmeyer HW, Miller M, De Leon-Jones F (1982) Anxiety and mood fluctuation during the normal menstrual cycle. Psychosom Med 44: 183-194.

Lande SD (1982) Physiological and subjective measures of anxiety during flooding. Behav Res Ther 20: 81-88.

Lang PJ, Melamed BG, Hart J (1970) A psychophysiological analysis of fear modification using an automated desensitization procedure. J Abnorm Psychol 76: 220-234.

Lee MA, Cameron OG, Greden JF (1985) Anxiety and caffeine consumption in people with anxiety disorders. Psychiatry Res 15: 211-217.

Levander-Lindgren M (1962) Studies in neurocirculatory asthenia (DaCosta's syndrome). I. Variations with regard to symptoms and some pathophysiological signs. Acta Med Scand 172: 665-676.

Liberthson R, Sheehan DV, King ME, Weyman AE (1986) The prevalence of mitral valve prolapse in patients with panic disorders. Am J Psychiatry 143: 511-515.

Lieberman JA, Brenner R, Lesser M, Coccaro E, Borenstein M, Kane JM (1983) Dexamethasone suppression tests in patients with panic disorder. Am J Psychiatry 140: 917-919.

Liebowitz MR, Fyer AJ, McGrath P, Klein DF (1981) Clonidine treatment of panic disorder. Psychopharmacol Bull 17: 122-123.

Liebowitz MR, Gorman JM, Fyer AJ, Dillon DJ, Klein DF (1984) Effects of naloxone on patients with panic attacks. Am J Psychiatry 141: 995-997.

Liebowitz MR, Gorman JM, Fyer AJ, Levitt M, Dillon D, Levy G, Appleby IL, Anderson S, Palij M, Davies SO, Klein DF (1985) Lactate provocation of panic attacks. II. Biochemical and physiological findings. Arch Gen Psychiatry 42: 709-719.

Lima DR, Turner P (1983) Propranolol increases reduced beta-receptor function in severely anxious patients. Lancet ii: 1505.

Lindemann CG, Zitrin CM, Klein DF (1984) Thyroid dysfunction in phobic patients. Psychosomatics 25: 603-606.

Lum LC (1975) Hyperventilation: the tip and the iceberg. J Psychosom Res 19: 375-383.

Lum LC (1976) The syndrome of habitual chronic hyperventilation. In: Hill $\mathrm{O}$ (Ed) Modern Trends in Psychosomatic Medicine: 3. Butterworth, London, pp 196-230.

Maas JW, Leckman JF (1983) Relationships between central nervous system noradrenergic function and plasma and urinary MHPG and other norepinephrine metabolites. In: Maas JW (Ed) MHPG: Basic Mechanisms and Psychopathology. Academic Press, New York, pp 33-43.

Magarian GJ (1982) Hyperventilation syndromes: infrequently recognized common expressions of anxiety and stress. Medicine 61: 219-236.

Mancia G, Zanchetti A (1981) Hypothalamic control of autonomic functions. In: Morgane PJ, Panksepp J (Eds) Handbook of the Hypothalamus, Vol 3B. Marcel Dekker, New York, pp 147-202.

Mantysaari M (1984) Hemodynamic reactions to circulatory stress tests in patients with neurocirculatory dystonia. Scand J Clin Lab Invest 44(suppl 140): 1-112.

Maple S, Bradshaw CM, Szabadi E (1982) Pharmacological responsiveness of sweat glands in anxious patients and healthy volunteers. BrJPsychiatry 141: 154-161.

Marangos PJ, Boulenger J-P (1985) Basic and clinical aspects of adenosinergic neuromodulation. Neurosci Biobehav Rev 9: 421-430.

Mason JW, Sachar EJ, Fishman JR, Hamburg DA, Handlon JH (1965) Corticosteroid responses to hospital admission. Arch Gen Psychiatry 13: 1-8.

Mathew RJ, Wilson WH (1986) Hematocrit and anxiety. J Psychosom Res 30: $307-311$.

Mathew RJ, Ho BT, Kralik P, Claghorn JM (1979) Anxiety and serum prolactin. Am J Psychiatry 136: 716-717.

Mathew RJ, Ho BT, Kralik P, Taylor D, Semchuk K, Weinman M, Claghorn JL (1980a) Catechol-0methyltransferase and catecholamines in anxiety and relaxation. Psychiatry Res 3: 85-91. 
Mathew RJ, Hsu LL, Semchuk K, Claghorn L (1980b) Acetylcholinesterase and pseudocholinesterase activities in anxiety. Am J Psychiatry 137: 1118-1120.

Mathew RJ, Ho BT, Kralik P, Taylor D, Claghom JL (1980c) MAO, DBH, and COMT: the effect of anxiety. $J$ Clin Psychiatry $41(12$ sect 2): 25-28.

Mathew RJ, Ho BT, Kralik P, Taylor DL, Claghorn JL (1981a) Catecholamines and monoamine oxidase activity in anxiety. Acta Psychiatr Scand 63: 245-252.

Mathew RJ, Ho BT, Taylor DL, Semchuk KM (1981b) Catecholamines and dopamine-B-hydroxylase in anxiety. J Psychosom Res 25: 499-504.

Mathew RJ, Ho BT, Francis DJ, Taylor DL, Weinman ML (1982) Catecholamines and anxiety. Acta Psychiatr Scand 65: 142-147.

Matuzas W, Al-Sadir J, Uhlenhuth EH, Glass RM (1987) Mitral valve prolapse and thyroid abnormalities in patients with panic attacks. Am J Psychiatry 144: 493-496.

McIntyre IM, Norman TR, Marriott PF, Burrows GD (1987) The pineal hormone melatonin in panic disorder. J Affect Disord 12: 203-206.

McKenzie JM (1979) Stress and thyroid function. In: Tolis G, Labrie F, Martin JB, Naftolin F (Eds) Clinical Neuroendocrinology: A Pathophysiological Approach. Raven Press, New York, pp 319-328.

McLeod DB, Hoehn-Saric R, Stefan RL (1986) Somatic symptoms of anxiety: comparison of self-report and physiological measures. Biol Psychiatry 21: 301-310.

Missri JC, Alexander S (1978) Hyperventilation syndrome. JAMA 240: 2093-2096.

Miyabo S, Hisada T, Asto T, Mizushima N, Uero K (1976) Growth hormone and cortisol responses to psychological stress: comparison of normal and neurotic subjects. J Clin Endocrinol Metab 42: 1158-1162.

Morrow GR, Labrum AH (1978) The relationship between psychological and physiological measures of anxiety. Psychol Med 8: 95-101.

Moyes ICA, Moyes RB (1977) Urinary 3'5'cyclic adenosine monophosphate (cAMP) as a measure of anxiety. Postgrad Med J 53(suppl 4): 41-46.

Nesse RM, Curtis GC, Brown GM, Rubin RT (1980) Anxiety induced by flooding therapy for phobias does not elicit prolactin secretory response. Psychosom Med 42: 25-31.

Nesse RM, Curtis GC, Brown GM (1982) Phobic anxiety does not affect plasma levels of thyroid stimulating hormone in man. Psychoneuroendocrinology 7: 69-74.

Nesse RM, Cameron OG, Curtis GC, McCann DS, Huber-Smith MJ (1984) Adrenergic function in patients with panic anxiety. Arch Gen Psychiatry 41: 771-776.

Nesse RM, Curtis GC, Thyer BA, McCann DS, Huber-Smith MJ, Knopf RF (1985a) Endocrine and cardiovascular responses during phobic anxiety. Psychosom Med 47: 320-332.

Nesse RM, Cameron OG, Buda AJ, McCann DS, Curtis GC, Huber-Smith MJ (1985b) Urinary catecholamines and mitral valve prolapse in panic anxiety patients. Psychiatry Res 14: 67-74.

Norman TR, Judd FK, Gregory M, James RH, Kember NM, McIntyre IM, Burrows GD (1986) Platelet serotonin uptake in panic disorder. J Affect Disord 11: 69-72.

Noyes R (1985) Beta-adrenergic blocking drugs in anxiety and stress. In: Curtis GC, Thyer BA, Rainey JM (Eds) Psychiatric Clinics of North America: Anxiety Disorders 8(1): 119-132.

Nutt DJ (1986) Increased central alpha 2 -adrenoreceptor sensitivity in panic disorder. Psychopharmacology 90: 268-269.

Nutt DJ, Frazer S (1987) Platelet binding studies in panic disorder. J Affect Disord 12: 7-11.

Okada F, Honma M, Ui M (1983) Plasma cyclic nucleotide responses to psychological stress in normal and neurotic subjects. J Clin Endocrinol Metab 57: 78-81.

Orr SP, Pitman RK (1987) Electrodermal psychophysiology of anxiety disorder: orienting response and spontaneous fluctuations. Biol Psychiatry 22: 653-656.

Ost L-G, Stemer U, Findahl I-L (1984) Physiological responses in blood phobics. Behav Res Ther 22: 109-117.

Pasternac A, Tubaa JF, Puddu PE, Krol RB, DeChamplain J (1982) Increased plasma catecholamine levels in patients with symptomatic mitral valve prolapse. Am J Med 73: 783-790.

Paul SM, Marangos PJ, Skolnick P (1981) The benzodiazepine-GABA-chloride ionophore receptor complex: common site of minor tranquilizer action. Biol Psychiatry 16: 213-229.

Paul SM, Skolnick P (1984) The biochemistry of anxiety: from pharmacotherapy to pathophysiology. In: Grinspoon L (Ed) Psychiatric Update, Vol III. American Psychiatric Press, Washington DC, pp 482-490.

Peronnet F, Blier P, Brisson G, Diamond P, Ledoux M, Valle M (1986) Plasma catecholamines at rest and exercise in subjects with high- and low-trait anxiety. Psychosom Med 48: 52-58.

Persky H, Grinker RR, Hamburg DA (1956) Adrenal cortical function in anxious human subjects. Arch Neurol Psychiatry 76: 549-558. 
Persson A, Elring E, Eriksson L, Farde L, Hedstrom C-G, Litton J-E, Mindus P, Sedvall G (1985) Imaging of [11C]-labelled R015-1788 binding to benzodiazepine receptors in the human brain by positron emission tomography. J Psychiat Res 19: 609-622.

Peterson GA, Ballenger JC, Cox DP, Hucek A, Lydiard RB, Laraia MT, Trockman C (1985) The dexamethasone suppression test in agoraphobia. J Clin Psychopharmacol 5: 100-102.

Phillips KA, Vaillant GE, Schnurr P (1987) Some physiologic antecedents of adult mental health. Am $J$ Psychiatry 144: 1009-1013.

Pincus JH, Tucker GJ (1985) Behavioral Neurology. Oxford University Press, New York, pp 287-292.

Pohl R, Ettedgui E, Bridges M, Lyraki H, Jimerson P, Kopin I, Rainey JM (1987) Plasma MHPG levels in lactate and isoproterenol anxiety states. Biol Psychiatry 22: 1127-1136.

Potter WZ, Muscettola G, Goodwin FK (1983) Sources of variance in clinical studies of MHPG. In: Maas JW (Ed) MHPG: Basic Mechanisms and Psychopathology. Academic Press, New York, pp 145-165.

Puddu PE, Pasternac A, Tubaa JF, Krol R, Farley L, DeChamplain J (1983) QT interval prolongation and increased plasma catecholamine levels in patients with mitral valve prolapse. Am Heart J 105: 422-428.

Pyke RE, Greenberg HS (1986) Norepinephrine challenges in panic attacks. J Clin Psychopharmacol 6: 279-285.

Quinton PM (1983) Sweating and its disorders. Annu Rev Med 34: 429-452.

Randall WC (1984) Nervous Control of Cardiovascular Function. Oxford University Press, Oxford.

Randall DC, Hasson DM (1982) Cardiac arrhythmias in the monkey during classically conditional fear and excitement. Pav J Biol Sci 16: 97-107.

Raskin M (1975) Decreased skin conductance response habituation in chronically anxious patients. Biol Psychol 2: 309-319.

Redmond DE (1979) New and old evidence for the involvement of a brain norepinephrine system in anxiety. In: Fann WE, Karacan I, Porkorny AD, Williams RL (Eds) Phenomenology and Treatment of Anxiety. SP Medical and Scientific Books, New York, pp 153-203.

Reichlin S (1985) Neuroendocrinology. In: Wilson JD, Foster DW (Eds) Williams' Textbook of Endocrinology. Saunders Company, Philadelphia, pp 492-567.

Rickels K (1981) Benzodiazepines: use and misuse. In: Klein DF, Rabkin JG (Eds) Anxiety: New Research and Changing Concepts. Raven Press, New York, pp 1-26,

Robertson HA (1979) Benzodiazepine receptors in "emotional" and "non-emotional" mice: comparison of four strains. Eur J Pharmacol 56: 163-166.

Rose RM (1980) Endocrine responses to stressful psychological events. In: Sachar EJ (Ed) Psychiatric Clinics of North America: Advances in Psychoneuroendocrinology 3(2): 251-276.

Rosenbaum AH, Schatzberg AF, Jost FA, Cross PD, Wells LA, Jiang N-S, Warnta T (1983) Urinary free cortisol levels in anxiety. Psychosomatics 24: 835-837.

Roth WT, Telch MJ, Taylor CB, Sachitano JA, Gallen CC, Kopell ML, McClenahan KL, Agras WS, Pfefferbaum A (1986) Autonomic characteristics of agoraphobia with panic attacks. Biol Psychiatry 21: 1133-1154.

Roy-Byrne PP, Uhde TW (1985) Panic disorder and major depression: biological relationships. Psychopharmacol Bull 21: 551-554.

Roy-Byrne PP, Uhde TW, Gold PW, Rubinow DR, Post RM (1985) Neuroendocrine abnormalities in panic disorder. Psychopharmacol Bull 21: 546-550.

Roy-Byme PP, Uhde TW, Sack DA, Linnoila M, Post RM (1986a) Plasma HVA and anxiety in patients with anxiety disorder. Biol Psychiatry 21: 849-853.

Roy-Byrne PP, Uhde TW, Post RM, Gallucci W, Chrousos GP, Gold PW (1986b) The corticotropin-releasing hormone stimulation test in patients with panic disorder. Am J Psychiatry 143: 896-899.

Rubinow DR, Roy-Byrne P (1984) Premenstrual syndromes: overview from a methodologic perspective. Am $J$ Psychiatry 141: 163-172.

Sainsbury PM, Gibson JG (1954) Symptoms of anxiety and tension and the accompanying physiological changes in the muscular system. INeurol Neurosurg Psychiatry 17: 216-224.

Sanghera MK, German DC (1983) The effects of benzodiazepine and non-benzodiazepine anxiolytics on locus coeruleus unit activity. J Neurol Transm 57: 267-279.

Sanghera MK, McMillen BA, German DC (1983) Buspirone, a non-benzodiazepine anxiolytic, increases locus coeruleus noradrenergic neuronal activity. Eur J Pharmacol 86: 107-110.

Schneider LS, Munjack D, Severson JA, Palmer R (1987) Platelet [ $\left.{ }^{3} \mathrm{H}\right]$ imipramine binding in generalized anxiety disorder, panic disonder, and agoraphobia with panic attacks. Biol Psychiatry 22: 59-66.

Schweizer EE, Swenson CM, Winokur A, Rickels K, Maislin G (1986a) The dexamethasone suppression test in generalized anxiety disorder. BrJ Psychiatry 149: 320-322. 
Schweizer E, Winokur A, Rickels K (1986b) Insulin-induced hypoglycemia and panic attacks. Am $J$ Psychiatry 143: 654-655.

Shear MK (1986) Pathophysiology of panic: a review of pharmacologic provocative tests and naturalistic monitoring data. J Clin Psychiatry $47(6$ suppl): $18-26$.

Shear MK, Kligfield P, Harshfield G, Devereux RB, Polan J, Mann JJ, Pickering T, Frances AJ (1987) Cardiac rate and rhythm in panic patients. Am J Psychiatry 144: 633-637.

Sheehan DV, Coleman JH, Greenblatt DJ, Jones KJ, Levine PH, Orsalak PJ, Peterson N, Schildkraut JJ, Uzogaru E, Watkins D (1983a) Some biochemical correlates of panic attacks with agoraphobia and their response to a new treatment. J Clin Psychopharmacol 4: 66-75.

Sheehan DV, Claycomb JB, Surman OS, Baer L, Coleman J, Gelles L (1983b) Panic attacks and the dexamethasone suppression test. Am J Psychiatry 140: 1063-1064.

Shulman R, Griffiths J, Diewold P (1978) Catechol-0-methyl transferase activity in patients with depressive illness and anxiety states. Br J Psychiatry 132: 133-138.

Smith OA, De Vito JL (1984) Central neural integration for the control of autonomic responses associated with emotion. Annu Rev Neurosci 7: 43-65.

Snyder SH, Sklar P (1984) Behavioral and molecular actions of caffeine: focus on adenosine. J Psychiat Res 18: 91-106.

Sobotka PA, Mayer JH, Bauernfeind RA, Kanakis C, Rosen KM (1981) Arrhythmias documented by 24-hour continuous ambulatory electrocardiographic monitoring in young women without apparent heart disease. Am Heart J 101: 753-758.

Svensson TH (1987) Peripheral, autonomic regulation of locus coeruleus noradrenergic neurons in brain: putative implications for psychiatry and psychopharmacology. Psychopharmacology 92: 1-7

Tan BK (1964) Physiological correlates of anxiety: a preliminary investigation of the orienting reflex. Can Psychiat Assoc J 9: 63-71.

Taylor CB, Telch MH, Havvik D (1982) Ambulatory heart rate changes during panic attacks. J Psychiat Res 17: 261-266.

Taylor CB, Sheikh J, Agras WS, Roth WT, Margraf J, Ehlers A, Maddock RJ, Gossard D (1986) Ambulatory heart rate changes in patients with panic attacks. Am J Psychiatry 143: 478-482.

Thyer BA, Matthews J (1986) The effect of phobic anxiety on plasma B-endorphin: a single-subject experiment. Behav Res Ther 24: 237-241,

Tuomisto J, Männistö P (1985) Neurotransmitter regulation of anterior pituitary hormones. Pharmacol Rev 37: 249-332.

Tyrer P, Lader MH (1976) Central and peripheral correlates of anxiety: a comparative study. J Nerv Ment Dis 162: $99-104$.

Tyrer P, Lee I, Alexander J (1980) Awareness of cardiac function in anxious, phobic, and hypochondriacal patients. Psychol Med 10: 171-174.

Uhde TW, Siever LJ, Post RM, Jimerson DC, Boulenger J-P, Buchsbaum MS (1982) The relationship of plasma free MHPG to anxiety and psychophysical pain in normal volunteers. Psychopharmacol Bull 18: 129-132.

Uhde TW, Boulenger J-P, Jimerson DC, Post RM (1984a) Caffeine: relationship to human anxiety, plasma MHPG, and cortisol. Psychopharmacol Bull 20: 426-430.

Uhde TW, Vittone BJ, Post RM (1984b) Glucose tolerance testing in panic disorder. Am J Psychiatry 141: $1462-1463$.

Uhde TW, Roy-Byme PP, Boulenger J-P, Vittone BJ, Post RM (1985) Phenomenology and neurobiology of panic disorder. In: Maser JD, Tuma AH (Eds) Anxiety and the Anxiety Disorders. Erlbaum, Hillsdale NJ, pp 557-576.

Uhde TW, Vittone BJ, Siever LJ, Kage WH, Post RM (1986) Blunted growth hormone response to clonidine in panic disorder patients. Biol Psychiatry 21: 1081-1085.

Uhde TW, Berrettini WH, Roy-Byme PP, Boulenger J-P, Post RM (1987) Platelet [ $\left.{ }^{3} \mathrm{H}\right]$ imipramine binding in patients with panic disorder. Biol Psychiatry 22: 52-58.

Ursin H, Baade E, Levine S (1978) Psychobiology of Stress: A Study of Coping Men. Academic Press, New York.

Van Toller C (1979) The Nervous Body: An Introduction to the Autonomic Nervous System and Behavior. Wiley, New York.

Veith JL, Anderson J, Slade SA, Thompson P, Langel GR, Getzlaf S (1984) Plasma B-endorphin, pain thresholds and anxiety levels across the human menstrual cycle. Physiol Behav 32: 31-34.

Verrier RL, Lown B (1984) Behavioral stress and cardiac arrhythmias. Annu Rev Physiol 46: 155-176.

Villacres EC, Hollifield M, Katon WJ, Wilkinson CW, Veith RC (1987) Sympathetic nervous system activity in panic disorder. Psychiatry Res 21: 313-321. 
Wheeler EO, White PD, Reed EW, Cohen ME (1950) Neurocirculatory asthenia (anxiety neurosis, effort syndrome, neurasthenia): a twenty year follow-up of one hundred and seventy-three patients. JAMA 142: 878-889.

Wing L (1964) Physiological effects of performing a difficult task in patients with anxiety states. $J$ Psychosom Res 7: 283-294.

Woods SW, Charney DS, Loke J, Gordman WK, Redmond DE, Heninger GR (1986) Carbon dioxide sensitivity in panic anxiety. Arch Gen Psychiatry 44: 900-909.

Woods SW, Charney DS, McPherson CA, Gradman AH, Heninger GR (1987) Situational panic attacks. Arch Gen Psychiatry 44: 365-375,

Wyatt RJ, Porkorny B, Kupfer D, Snyder F, Engelman K (1971) Resting plasma catecholamine concentrations in patients with depression and anxiety. Arch Gen Psychiatry 24: 65-70.

Yeragani UK, Pohl R, Balon R, Weinberg P, Berchou R, Rainey JM (1987) Preinfusion anxiety predicts lactate-induced panic attacks in normal controls. Psychosom Med 49: 383-389.

Yu PH, Bowen R, Carlson K, O'Sullivan K, Boulton AA (1982) Comparison of biochemical properties of platelet monoamine oxidase in mentally disordered and healthy individuals. Psychiatry Res 6: 107-121.

Ziegler MG, Lake CR (1984) Norepinephrine. Williams and Wilkins, Baltimore.

Zohar J, Insel TR (1987) Obsessive-compulsive disorder: psychobiological approaches to diagnosis, treatment, and pathophysiology. Biol Psychiatry 22: 667-687. 